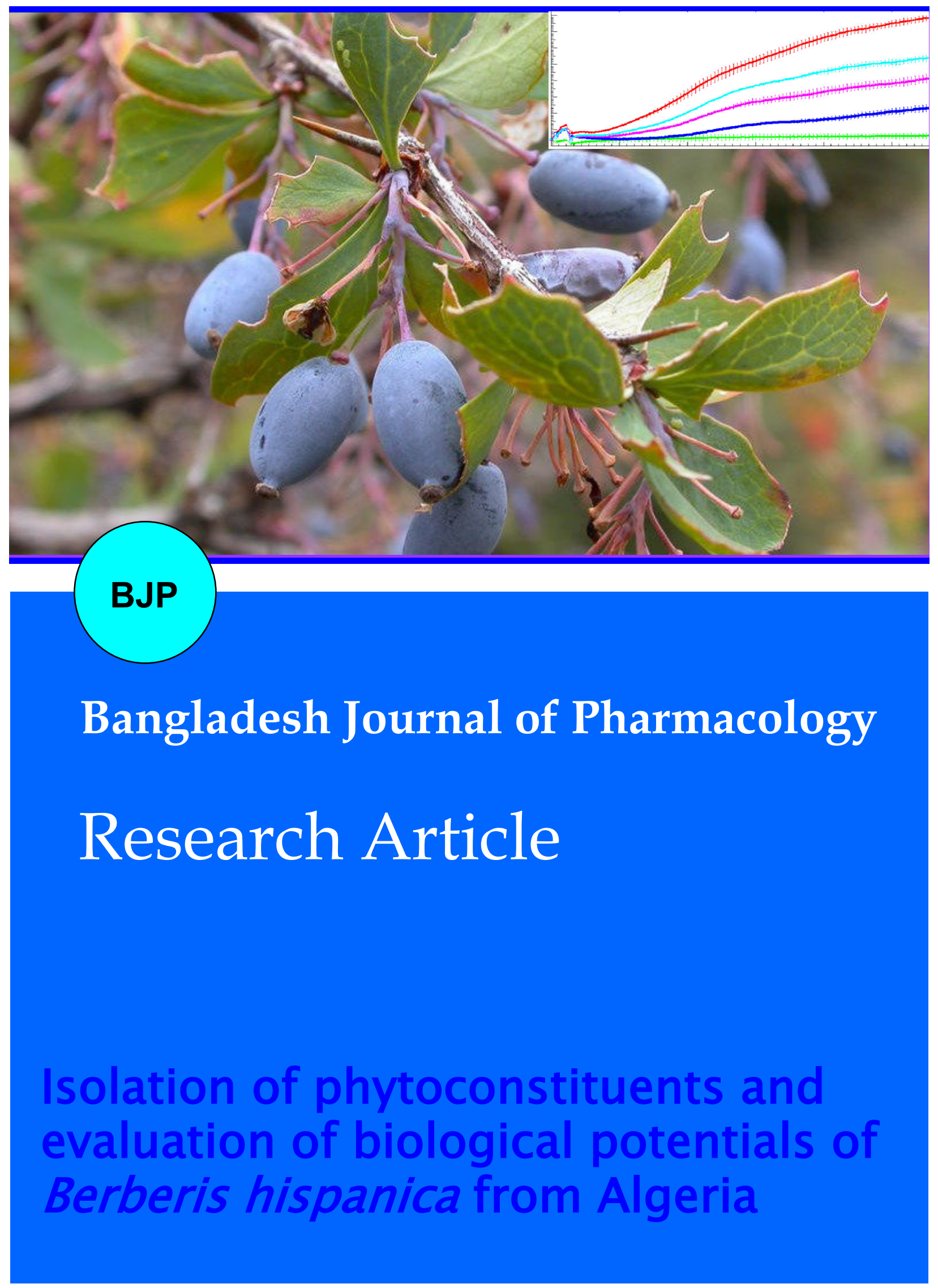


Abstracted/indexed in Academic Search Complete, Agroforestry Abstracts, Asia Journals Online, Bangladesh Journals Online, Biological Abstracts, BIOSIS Previews, CAB Abstracts, Current Abstracts, Directory of Open Access Journals, EMBASE/Excerpta Medica, Global Health, Google Scholar, HINARI (WHO), International Pharmaceutical Abstracts, Open J-gate, Science Citation Index Expanded, SCOPUS and Social Sciences Citation Index

ISSN: $1991-0088$

\title{
Isolation of phytoconstituents and evaluation of biological potentials of Berberis hispanica from Algeria
}

\author{
Redouane Lemoui ${ }^{1}$, Samira Benyahia ${ }^{1}$, Labib Noman², Ilham Bencherchar ${ }^{1}$, Feyza Oke- \\ Altuntas3, Khellaf Rebbas4, Samir Benayache', Fadila Benayache' and Ibrahim Demirtas²
}

${ }^{1}$ Unité de Recherche Valorisation des Ressources Naturelles, Molécules Bioactives et Analyses Physicochimiques et Biologiques. Université Frères Mentouri, Constantine, Route d'Ain El Bey 25000, Constantine, Algérie;

${ }^{2}$ Laboratory of Plant Research, Department of Chemistry, Faculty of Science, Cankiri Karatekin University, Cankiri, Turkey; 'Department of Biology, Faculty of Science, Gazi University, Ankara'06500, Turkey; 'Université de M'Sila, 28000 M’Sila, Algérie.

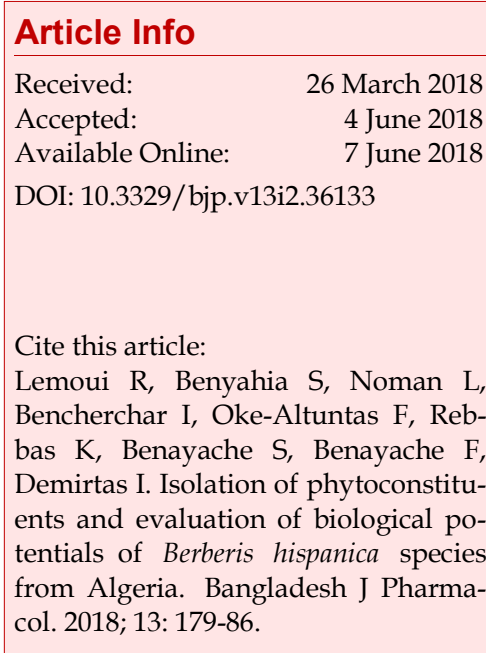

\begin{abstract}
The aim of this study was to isolate the phytoconstituents and evaluate the biological activities of Berberis hispanica. Three phenolic compounds (tamarixetin, caffeic acid and rutin) were isolated from B. hispanica. The structures of the pure compounds were elucidated by spectroscopic and mass-spectrometric analyses, including 1D-, 2D-NMR, and HPLC-TOF/MS. In addition, antimicrobial, anti-oxidant and anti-proliferative effects of the extracts, some fractions and isolated compounds were evaluated. The extracts of B. hispanica were evaluated against six bacterial strains and exhibited the highest activity against Klebsiella pneumonia $(15 \mathrm{~mm}$ at $100 \mathrm{mg} / \mathrm{mL})$. Fraction $\mathrm{T} 36\left(\mathrm{IC}_{50}<5 \mu \mathrm{g} /\right.$ $\mathrm{mL}$ ) from the $n$-butanol extract displayed higher radical scavenging activity than butylated hydroxytoluene. The isolated compounds were evaluated for their anti-proliferative effects against human cervical adenocarcinoma (HeLa) cell line by real time cell analyzer assay and tamarixetin exhibited the remarkable effect $\left(\mathrm{IC}_{50}<50 \mu \mathrm{g} / \mathrm{mL}\right)$ on HeLa cells. This study supports the documented medicinal effects of B. hispanica.
\end{abstract}

\section{Introduction}

Plant is considered as nature's chemical factory for providing the chemical compounds, and as a source of novel therapeutic compounds (Arora et al., 2003). Several studies have been reported on the antibacterial and anti-oxidant activities of the plant extracts, which may be due to the presence of the natural phenolic compounds (Silva et al., 2010; Prakash et al., 2009). Phenolic compounds play important roles in plants and disease resistance (Servili and Montedoro, 2002; Silva et al., 2006).

The genus Berberis (Berberidaceae) includes about 500 species distributed largely in Europe, Northeastern region of the United States, Asia and Africa (Harish, 2012; Mokhber-Dezfuli et al., 2014). Many studies have been reported on the medicinal properties of this genus. It has been employed in cholecystitis, cholelithiasis, jaundice, dysentery, leishmaniasis, malaria, gall stones, hypertension, ischemic heart disease, cardiac arrhythmias and cardiomyopathies (Mokhber-Dezfuli et al., 2014). Different types of chemical constituents were found in the B. jaeschkeana and B. thunbergii species such as alkaloids, glycosides, flavonoids, steroids, saponins reducing sugars and terpenoids (Hussain et al., 2016; Alamzeb et al., 2013).

The plant B. hispanica is a deciduous thorny shrub. The infusion of the stem bark of this plant has been used in 
traditional medicine to treat the gastro-intestinal infections, inflammation, liver and biliary disorders (ElYoubi et al., 2012a; Bellakhdar, 1997). But, a few studies have been reported on its biological activities and phytochemical analysis (El-Youbi et al., 2012b).

Therefore, this study was undertaken in order to investigate the biological activities of the extracts from $B$. hispanica by various methods, along with to isolate and identificate of its secondary metabolites, and to evaluate the antiproliferative effect of the isolated phenolic compounds on the growth of HeLa cell lines by xCELLigence method.

\section{Materials and Methods}

\section{General experimental procedure}

NMR measurements were performed on a Bruker Avence III spectrometer in DMSO- $\mathrm{d}_{6}, \mathrm{CDCl}_{3}$ or $\mathrm{CD}_{3} \mathrm{OD}$ (1H-NMR $600 \mathrm{MHz}$; ${ }^{13} \mathrm{C}-\mathrm{NMR} 150 \mathrm{MHz}$ ). Chemical shifts were given in ppm with tetramethylsilane (TMS) as an internal standard. HPLC-TOF/MS spectrum was recorded in the negative ion mode on an Agilent 6210 spectrometer. ESI-MS analyses were performed in the positive ion mode within the $\mathrm{m} / \mathrm{z}$ range $100-2000$, using a LTQ XL Linear Ion Trap 2D instrument (Thermo Scientific, USA) equipped with Xcalibur ${ }^{\circledR}$ software (Thermo Scientific, USA). Column chromatography was carried out on silica gel (Merck, 60-230 mesh) in glass columns in open atmosphere pressure. For thin-layer chromatography, silica gel F254 (Merck) precoated plates were used. Compounds were detected under UV $(254 \mathrm{~nm})$ and sprayed with $5 \%$ ceric sulfate $\mathrm{H}_{2} \mathrm{SO}_{4}$ reagent, followed by heating at $105^{\circ} \mathrm{C}$ for $1-2 \mathrm{~min}$.

\section{Collection and identification of plant material}

The aerial parts of B. hispanica was collected from the Cherea Mountain in July 2009 and was identified by Prof. Rebbas Khelaf, Department of Botany, Faculty of Science, M'Sila University, Algeria.

\section{Extraction of plant material}

The aerial parts of $B$. hispanica (963 g) were macerated at room temperature with ethanol-water $(7: 3, v / v)$ for three days to obtain the crude extract $(87 \mathrm{~g})$. The crude extract of ethanol-water $(7: 3, \mathrm{v} / \mathrm{v})$ was dissolved in the distilled water $(1 \mathrm{~L})$, and first extracted with petroleum ether to yielded $(4.3 \mathrm{~g})$, after that the aqueous was extracted with chloroform to obtain $(2.3 \mathrm{~g})$, then with ethyl acetate $(6.1 \mathrm{~g})$. Finally with $n$-butanol to yielded (30.6 g). The ethyl acetate extract ( $5 \mathrm{~g}$ ) was subjected on a silica gel column eluted with acetone-chloroform (1:3, $\mathrm{v} / \mathrm{v}$ ) to obtain 56 fractions (S), the precipitate from fraction S8 was purified by TLC eluted with acetonechloroform $(1: 4, \mathrm{v} / \mathrm{v})$ to afford compound $\mathbf{1}$ (tamarixetin). Fraction $\mathrm{S} 24$ was precipitated and purified by the TLC eluted with acetone-chloroform $(2: 4, \mathrm{v} / \mathrm{v})$ to afford the compound 2 (caffeic acid). The $n$-butanol extract (25 g) was then loaded on a silica gel column. The column was eluted with hexane-dichloromethane (100:0-0:100), and dichloromethane-ethyl acetate (100:0$0: 100)$, after that by ethyl acetate-methanol (100:0-0:100) solvent systems, which yielded 69 fractions $(\mathrm{T})$, the fractions T45, T46 and T47 were combined (10 g), then loaded to a silica gel column, and eluted with chloroform-methanol (100:0-0:100) solvent systems, which yielded 25 fractions $(X)$. Fraction X18 was purified by the TLC eluted with ethyl acetate-methanol -water (7.5:1:1, v/v/v) to afford compound 3 (rutin).

\section{Chemicals used in the biological tests}

Anhydrous sodium carbonate, Folin-Ciocalteu's phenol reagent, methanol were purchased from the Merck (Germany). 2,2-Diphenyl-1-picrylhydrazyl (DPPH), gallic acid, 2,6-di-tert-butyl-4-methylphenol (BHT), dimethyl sulfoxide (DMSO), trypsin-EDTA, fetal bovine serum (FBS), penicillin/streptomycin and Dulbecco's modified Eagle's medium-high glucose (DMEM-HG) were purchased from Sigma-Aldrich $\mathrm{GmbH}$ (Germany). All other chemicals were analytical grade and obtained from either Sigma or Merck.

\section{Determination of anti-oxidant activity}

Radical scavenging activity was determined according to the method described elsewhere (Blois, 1958). The solution of DPPH in methanol $(0.004 \%)$ was prepared fresh daily and $1 \mathrm{~mL}$ of this solution in methanol was mixed with $1 \mathrm{~mL}$ of sample solution of varying concentrations. Each mixture was kept in the dark for $30 \mathrm{~min}$ at room temperature and the absorbance was measured at $517 \mathrm{~nm}$ against a blank on a UV visible light spectrophotometer (Rayleigh, UV-2601). BHT was used as a positive control. Scavenging of DPPH radical was calculated according to the formula:

Radical scavenging $\%=\left[\left(\mathrm{A}_{\text {control }}-\mathrm{A}_{\text {sample }}\right) / \mathrm{A}_{\text {control }}\right] \times 100$

\section{Determination of total phenolic content}

Total phenolic contents of the samples were analysed according to the Folin-Ciocalteu method (Singleton and Rossi, 1965). Briefly, $0.1 \mathrm{~mL}$ of sample solution, $0.2 \mathrm{~mL}$ of $50 \%$ Folin-Ciocalteu's reagent and $1 \mathrm{~mL}$ of $2 \%$ $\mathrm{Na}_{2} \mathrm{CO}_{3}$ was mixed in a tube. Then, the mixture was incubated at room temperature for $45 \mathrm{~min}$. The absorbance of each mixture was measured at $760 \mathrm{~nm}$. The same procedure was also applied to the standard solutions of gallic acid. Total phenolic contents were expressed as $\mu \mathrm{g}$ gallic acid equivalents per $\mathrm{mg}$ of the samples.

\section{Determination of total flavonoids content}

The total flavonoid content was determined by the method of aluminum trichloride using quercetin as a reference (Singleton et al., 1965). $1 \mathrm{~mL}$ of ethyl acetate and $n$-butanol extracts of aerial parts $(1 \mathrm{mg} / \mathrm{mL})$ was 
mixed with $1 \mathrm{~mL}$ of $2 \%$ methanolic aluminum trichloride solution. The absorbance at $420 \mathrm{~nm}$ was read after 1 hour. All determinations were realized in couple. The absorption of quercetin standard solutions (15.6 to 1000 $\mu \mathrm{g} / \mathrm{mL}$ ) was measured in the same conditions. The results are expressed as equivalent quercetin $\mu \mathrm{QE} / \mathrm{mg}$ of extract.

\section{Determination of antibacterial activity}

The following strains of bacteria were used as test microorganisms: Acinetobacter oxy, Escherichia coli, Enterococcus faecalis, Proteus mirabilis, Klebsiella pneumoniae ATTC 700603 and Pseudomonas aeruginosa ATTC 27853. These microorganisms were obtained from the Microbiology Laboratory, Faculty of Medicine, Badji Mokhtar University.

The dried extract was dissolved in sterile dimethyl sulfoxide (DMSO). Disc diffusion method was used to investigate the antimicrobial activity of the extracts (Toudert et al., 2009; Nascimento et al., 2000). The agar gel (MHA) was treated with the appropriate microorganism suspension (each microorganism was inoculated at a concentration of $10^{6}$ colony forming units per $\mathrm{mL}$ ), and the antimicrobial activities of the extracts that penetrate into the agar by diffusion was measured. The assays were based on the use of sterile discs filter paper (6 mm diameter) impregnated with $20 \mu \mathrm{L}$ of the extract solution to be examined and allowed to dry at room temperature. A sterile disc impregnated with DMSO was used as a negative control. After incubation for 24 hours at $37^{\circ} \mathrm{C}$, all plates were observed for zone of growth inhibition and the diameter of these zones was measured in millimeters. All experiments were performed in triplicates.

\section{Determination of antiproliferative activity}

Antiproliferative effects of the samples (rutin, tamarixetin, fraction T45-47 and $n$-butanol extract) were investigated on HeLa cell lines by xCELLigence realtime cell analyzer-single plate (RTCA-SP) instrument (Roche Applied Science, Switzerland) (Oke-Altuntas et al., 2016). Dulbecco's Modified Eagle Medium (DMEM) with $10 \%$ fetal bovine serum and $2 \%$ penicillin-streptomycin was used as the cell culture medium. First, $50 \mu \mathrm{L}$ of the medium was added to each of a 96-well E-plate and kept in the hood for $15 \mathrm{~min}$ and then in an incubator for $15 \mathrm{~min}$ to allow the electrodes to equilibrate with the culture medium. The E-plate was inserted in the RTCA station of the incubator and a background measurement was taken, $100 \mu \mathrm{L}$ HeLa cell suspensions were then added to the wells to obtain a $2.5 \times 10^{4}$ cell/well concentration in each well except three. $100 \mu \mathrm{L}$ of medium was added to these three wells instead of the cell suspension. After $30 \mathrm{~min}$, the E-plate was inserted in the RTCA station and a second set of measurements was initiated for $80 \mathrm{~min}$. After this step, solutions of the samples that were prepared with
DMSO (final concentration of DMSO was less than 1\% in each of the wells) and medium were added to the wells to obtain final concentrations in each well, respectively. Upon completion, the final volume of the wells was $200 \mu \mathrm{L}$ including the medium. After this, the main measurement period of 48 hours was initiated in $10 \mathrm{~min}$ intervals in triplicate.

\section{Statistical analysis}

The results were expressed as means \pm standard deviations (SD). Statistical analyses were performed using the SPSS 11.5 (USA). Differences among means were done by analysis of variance (ANOVA). Pearson's correlation analysis was used for comparisons of total phenolic contents and the anti-oxidant activity of the fractions.

\section{Results}

\section{Identification of isolated compounds}

All the compounds shown in Figure 1 were isolated for the first time from this plant, and the spectral data led to identification of two flavonoids and phenolic acid:

Tamarixetin (1): yellow powder. ${ }^{1} \mathrm{H}-\mathrm{NMR}$ (DMSO-d ${ }_{6}$, $600 \mathrm{MHz}): 3.82\left(3 \mathrm{H}, \mathrm{s}, 4{ }^{\prime}-\mathrm{OCH}_{3}\right), 6.17(1 \mathrm{H}, d, J=1.76 \mathrm{~Hz}$, $\mathrm{H}-6), 6.45(1 \mathrm{H}, d, J=1.76 \mathrm{~Hz}, \mathrm{H}-8), 6.92(1 \mathrm{H}, d, J=8.80$ $\mathrm{Hz}, \mathrm{H}-5$ '), 7.67 (1H, dd, J = 8.80-2.35 Hz, H-6'), $7.73(1 \mathrm{H}$, $\left.d, J=2.35 \mathrm{~Hz}, \mathrm{H}-2^{\prime}\right), 9.40$ (1H, s, 3'-OH), 9.72 (1H, s, 3$\mathrm{OH}), 10.76(1 \mathrm{H}, \mathrm{s}, 7-\mathrm{OH}), 12.45(1 \mathrm{H}, \mathrm{s}, 5-\mathrm{OH}) ;{ }^{13} \mathrm{C}-\mathrm{NMR}$ (DMSO-d $6,150 \mathrm{MHz}): 56.26$ (4'-OCH3), 94.09 (C-8), 98.69 (C-6), 103.36 (C-10), 112.25 (C-2'), 116.06 (C-5'), 122.39 (C-1'), 122.24 (C-6'), 132.00 (C-3), 146.96 (C-2), 147.80 (C-3'), 149.25 (C-4'), 156.65(C-9), 161.24 (C-5), 164.52 (C-7), 175.05 (C-4). Molecular formula $\mathrm{C}_{16} \mathrm{H}_{12} \mathrm{O}_{7}$. (Saewan et al., 2011).

Caffeic acid (2): yellow powder. ${ }^{1} \mathrm{H}-\mathrm{NMR}$ (DMSO-d $\mathrm{d}_{6}$, $600 \mathrm{MHz}): 6.16(1 \mathrm{H}, \mathrm{d}, J=15.85 \mathrm{~Hz}, \mathrm{H}-8), 6.74(1 \mathrm{H}, \mathrm{d}, J=$ $8.22 \mathrm{~Hz}, \mathrm{H}-5), 6.94(1 \mathrm{H}, \mathrm{dd}, J=8.22-2.35 \mathrm{~Hz}, \mathrm{H}-6), 7.00$ $(1 \mathrm{H}, \mathrm{d}, J=2.35 \mathrm{~Hz}, \mathrm{H}-2), 7.40(1 \mathrm{H}, \mathrm{d}, J=15.85 \mathrm{~Hz}, \mathrm{H}-7)$, 9.10-9.50 (3H, s, 3, 4, 9-OH); ${ }^{13} \mathrm{C}-\mathrm{NMR}$ (DMSO-d 6150 MHz): 115.07 (C-2), 115. 57 (C-8), 116. 18 (C-5), 121.55 (C -6), 126.14 (C-1), 144.98 (C-7), 145.99 (C-3), 148.56 (C-4), 168.28 (C-9). Molecular formula $\mathrm{C}_{9} \mathrm{H}_{8} \mathrm{O}_{4}$ (Bhatt, 2011).

Rutin (3): yellow powder. HPLC-TOF/MS [M-H]- at $m / z$ 609, ${ }^{1} \mathrm{H}-\mathrm{NMR}$ (DMSO-d $\left.6,600 \mathrm{MHz}\right): 0.98(3 \mathrm{H}, \mathrm{d}, J=6.46$ Hz, H-6"'), 3.08 (1H, m, H-4"'), 3.25 (1H, m, H-5"'), 3.30 $\left(1 \mathrm{H}, d d, J=9.39-2.93 \mathrm{~Hz}, \mathrm{H}-3^{\prime \prime \prime}\right), 3.40(1 \mathrm{H}, d d, J=2.93-$ $\left.1.76 \mathrm{~Hz}, \mathrm{H}-22^{\prime \prime}\right), 4.37$ (1H, d, J= $\left.1.76 \mathrm{~Hz}, \mathrm{H}-1^{\prime \prime \prime}\right), 3.03-3.28$ (3H, m, H-2", H-3", H-4", H-5"), 3.18, 3.27 (1H, m, $\left.\mathrm{H}_{a}-6^{\prime \prime}\right)$, $3.68\left(1 \mathrm{H}, \mathrm{d}, J=10.56 \mathrm{~Hz}, \mathrm{H}_{\mathrm{b}}-6^{\prime \prime}\right), 5.29(1 \mathrm{H}, d, J=7.63 \mathrm{~Hz}$, H-1"), $6.13(1 \mathrm{H}, d, J=1.76 \mathrm{~Hz}, \mathrm{H}-6), 6.32(1 \mathrm{H}, d, J=1.76$ $\mathrm{Hz}, \mathrm{H}-8), 6.80\left(1 \mathrm{H}, d, J=8.22 \mathrm{~Hz}, \mathrm{H}-5^{\prime}\right), 7.49(1 \mathrm{H}, d, J=$ $\left.1.76 \mathrm{~Hz}, \mathrm{H}-2^{\prime}\right), 7.52\left(1 \mathrm{H}, d d, J=8.22-1.76 \mathrm{~Hz}, \mathrm{H}-6^{\prime}\right) ;{ }^{13} \mathrm{C}-$ NMR (DMSO-d, $150 \mathrm{MHz}): 18.18$ (C-6"'), 67.39 (C-6"), 68.69 (C-5"'), 70.73 (C-4"), 70.79 (C-2"'), 70.99 (C-3"''), 


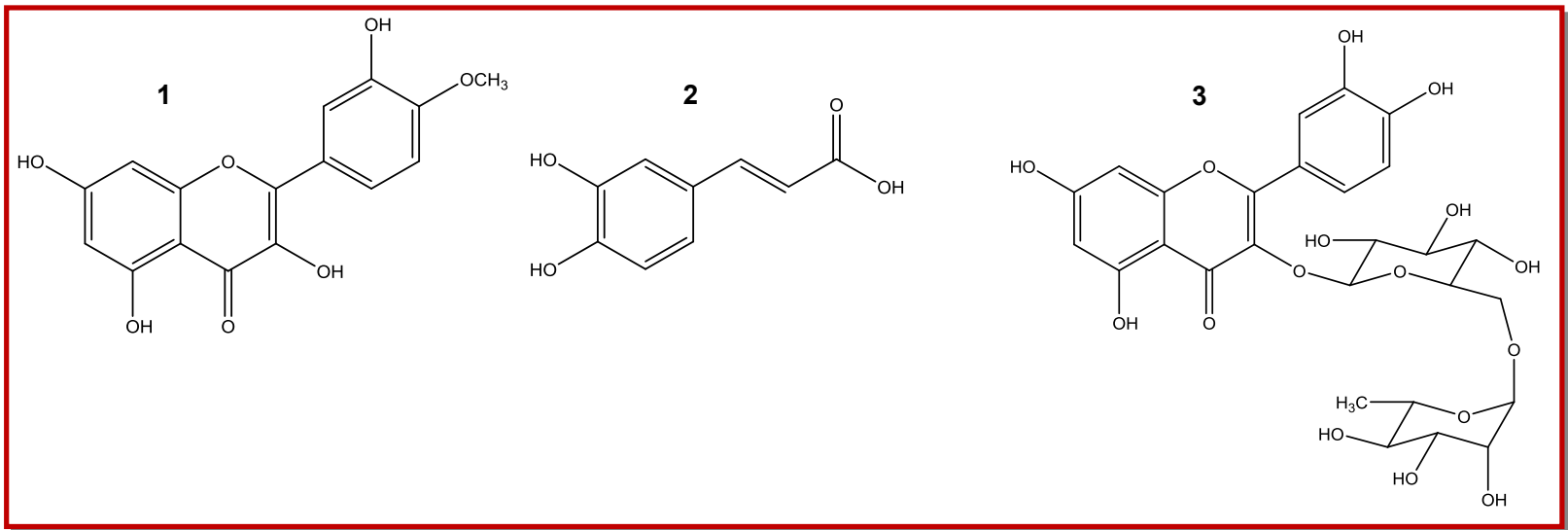

Figure 1: The structures of the isolated compounds

\begin{tabular}{|l|c|c|c|}
\hline \multicolumn{4}{|c|}{ Table I } \\
\hline \multicolumn{4}{|c|}{ Radical scavenging activity and total } \\
phenolic/flavonoids contents of the extracts
\end{tabular}

72.35 (C-4'"'), 74.05 (C-2"'), 76.29 (C-3"'), 76.96 (C-5"), 94.32 (C-8), 99.69 (C-6), 101.23 (C-1"'), 101.97 (C-1"), 103.54 (C-10), 115.80 (C-5'), 116.61 (C-2'), 121.23 (C-1'), 121.98 (C-6'), 133.58 (C-3), 145.51 (C-3'), 149.52 (C-4'), 156.79 (C-2), 157.00 (C-9), 161.49 (C-5), 166.50 (C-7), 177.44 (C-4). Molecular formula is $\mathrm{C}_{27} \mathrm{H}_{30} \mathrm{O}_{16}$. Spectral data were compared with published literature (Sintayehu et al., 2016).

\section{Anti-oxidant activity}

Ethyl acetate extract $\left(\mathrm{IC}_{50}=79.8 \mu \mathrm{g} / \mathrm{mL}\right.$ ) showed higher radical scavenging effect than the $n$-butanol extract $\left(\mathrm{IC}_{50}=136.2 \mu \mathrm{g} / \mathrm{mL}\right)$ (Table I). The highest free radical scavenging was observed for fraction $\mathrm{T} 36\left(\mathrm{IC}_{50}<5 \mu \mathrm{g} /\right.$ $\mathrm{mL}$ ) and this fraction exhibited higher $\mathrm{DPPH}$ scavenging activity than the synthetic anti-oxidant BHT $\left(\mathrm{IC}_{50}=23.1 \pm 0.2 \mu \mathrm{g} / \mathrm{mL}\right.$ ) (Figure 2).

On the other hand, total phenolic and flavonoid contents of the extracts were also determined. n-Butanol extract contained higher phenolic and flavonoid contents than ethyl acetate extract (Table I). Among the fractions, the highest total phenolic content was found in fraction T36 $(442.5 \mu \mathrm{g})$ isolated from the $n$-butanol extract. The contents of total phenolic compounds in the tested fractions ranged between 14.3 to $442.5 \mu \mathrm{g} / \mathrm{mg}$ (Table II). A significant correlation $(\mathrm{R}=0.945, \mathrm{p}<0.01)$ was observed between the total phenolic content and $\mathrm{DPPH}$ scavenging activity of the fractions indicating

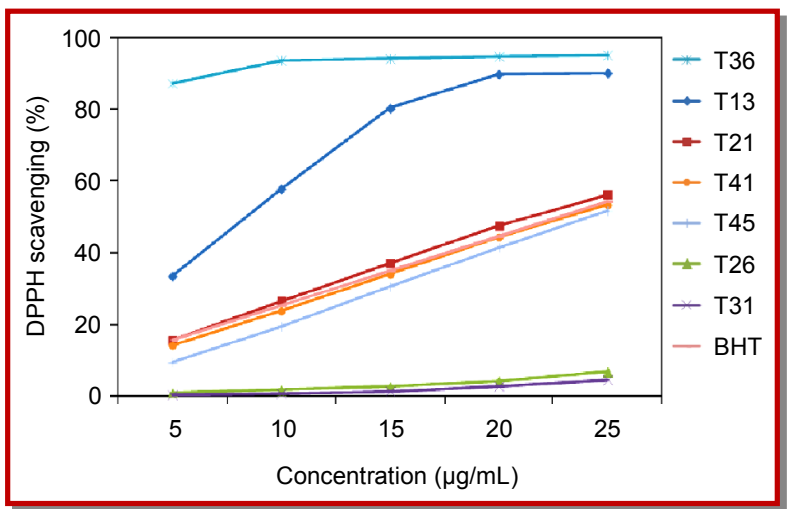

Figure 2: DPPH scavenging activity of the fractions from $n$ buanol extract at tested concentrations

phenolic compounds were primarily responsible for this activity.

\section{Antimicrobial activity}

The results of the antibacterial activity of the crude $n$ butanol and ethyl acetate extracts of $B$. hispanica are

\begin{tabular}{|c|c|c|}
\hline \multicolumn{3}{|c|}{ Table II } \\
\hline \multicolumn{3}{|c|}{$\begin{array}{l}\text { Radical scavenging activity and total } \\
\text { phenolics contents of the fractions* }\end{array}$} \\
\hline Fractions & $\begin{array}{l}\text { DPPH scavenging } \\
\text { IC }_{50}(\mu \mathrm{g} / \mathrm{mL})\end{array}$ & $\begin{array}{l}\text { Total phenolic content } \\
\mu \mathrm{g} \text { GAE/mg extract }\end{array}$ \\
\hline $\mathrm{T} 21$ & $23.8 \pm 0.2^{\mathrm{b}}$ & $178.1 \pm 0.9^{\mathrm{d}}$ \\
\hline T41 & $22.8 \pm 0.5^{b}$ & $214.5 \pm 0.9 \mathrm{~b}$ \\
\hline T45- 47 & $24.1 \pm 0.5^{b}$ & $169.5 \pm 0.5^{\mathrm{e}}$ \\
\hline T36 & $<5$ & $442.5 \pm 0.6^{\mathrm{a}}$ \\
\hline T26 & $98.5 \pm 0.5^{d}$ & $44.5 \pm 0.8^{f}$ \\
\hline T31 & $>100$ & $14.3 \pm 0.7 \mathrm{~g}$ \\
\hline BHT & $23.1 \pm 0.1^{b}$ & ND \\
\hline EDTA & ND & ND \\
\hline \multicolumn{3}{|c|}{$\begin{array}{l}\text { *Values represent averages } \pm \text { standard deviations for triplicate } \\
\text { experiments. Values in the same column with different superscripts } \\
\text { are significantly }(p<0.05) \text { different, ND: Not determined }\end{array}$} \\
\hline
\end{tabular}


Table III

\section{Antimicrobial activity of the B. hispanica extracts*}

\begin{tabular}{|c|c|c|c|c|c|c|c|c|c|c|c|c|}
\hline \multirow[t]{2}{*}{$\begin{array}{l}\text { Microorgan- } \\
\text { ism }\end{array}$} & \multicolumn{6}{|c|}{$\begin{array}{l}n \text {-Butanol extract } \\
(\mathrm{mg} / \mathrm{mL})\end{array}$} & \multicolumn{6}{|c|}{$\begin{array}{l}\text { Ethyl acetate extract } \\
\qquad(\mathrm{mg} / \mathrm{mL})\end{array}$} \\
\hline & 3.1 & 6.3 & 12.5 & 25 & 50 & 100 & 3.1 & 6.3 & 12.5 & 25 & 50 & 100 \\
\hline $\begin{array}{l}\text { Acinetobacter. } \\
\text { oxy }\end{array}$ & $\begin{array}{r}6.2 \\
(0.2)\end{array}$ & $\begin{array}{r}8.1 \\
(0.2)\end{array}$ & $\begin{array}{l}13.8 \\
(0.2)\end{array}$ & $\begin{array}{l}14.1 \\
(0.1)\end{array}$ & $\begin{array}{l}14.3 \\
(0.3)\end{array}$ & $\begin{array}{l}15.2 \\
(0.2)\end{array}$ & $\begin{array}{r}5.8 \\
(0.2)\end{array}$ & $\begin{array}{r}6.0 \\
(0.1)\end{array}$ & $\begin{array}{r}6.3 \\
(0.1)\end{array}$ & $\begin{array}{r}9.8 \\
(0.3)\end{array}$ & $\begin{array}{l}10.2 \\
(0.2)\end{array}$ & $\begin{array}{l}15.0 \\
(0.2)\end{array}$ \\
\hline E. coli & $\begin{array}{r}7.2 \\
(0.3)\end{array}$ & $\begin{array}{r}8.0 \\
(0.3)\end{array}$ & $\begin{array}{l}12.9 \\
(0.2)\end{array}$ & $\begin{array}{l}13.2 \\
(0.3)\end{array}$ & $\begin{array}{l}14.3 \\
(0.3)\end{array}$ & $\begin{array}{l}14.9 \\
(0.1)\end{array}$ & $\begin{array}{r}6.8 \\
(0.1)\end{array}$ & $\begin{array}{r}6.0 \\
(0.1)\end{array}$ & $\begin{array}{r}6.1 \\
(0.2)\end{array}$ & $\begin{array}{r}6.2 \\
(0.2)\end{array}$ & $\begin{array}{r}7.1 \\
(0.1)\end{array}$ & $\begin{array}{l}12.2 \\
(0.2)\end{array}$ \\
\hline $\begin{array}{l}\text { Enterococcus } \\
\text { faecalis }\end{array}$ & $\begin{array}{r}5.8 \\
(0.2)\end{array}$ & $\begin{array}{r}6.1 \\
(0.2)\end{array}$ & $\begin{array}{l}10.9 \\
(0.1)\end{array}$ & $\begin{array}{l}13.4 \\
(0.3)\end{array}$ & $\begin{array}{l}14.0 \\
(0.2)\end{array}$ & $\begin{array}{l}14.1 \\
(0.2)\end{array}$ & $\begin{array}{r}5.9 \\
(0.1)\end{array}$ & $\begin{array}{r}5.9 \\
(0.1)\end{array}$ & $\begin{array}{r}6.3 \\
(0.3)\end{array}$ & $\begin{array}{l}11.9 \\
(0.1)\end{array}$ & $\begin{array}{l}12.1 \\
(0.2)\end{array}$ & $\begin{array}{l}15.0 \\
(0.2)\end{array}$ \\
\hline $\begin{array}{l}\text { Proteus mira- } \\
\text { bilis }\end{array}$ & $\begin{array}{r}5.7 \\
(0.3)\end{array}$ & $\begin{array}{r}5.8 \\
(0.2)\end{array}$ & $\begin{array}{r}5.9 \\
(0.2)\end{array}$ & $\begin{array}{r}6.2 \\
(0.2)\end{array}$ & $\begin{array}{r}6.3 \\
(0.3)\end{array}$ & $\begin{array}{r}6.4 \\
(0.3)\end{array}$ & $\begin{array}{r}5.9 \\
(0.1)\end{array}$ & $\begin{array}{r}5.9 \\
(0.1)\end{array}$ & $\begin{array}{r}6.1 \\
(0.1)\end{array}$ & $\begin{array}{r}6.2 \\
(0.2)\end{array}$ & $\begin{array}{r}6.3 \\
(0.3)\end{array}$ & $\begin{array}{l}10.0 \\
(0.1)\end{array}$ \\
\hline $\begin{array}{l}\text { Klebsiella } \\
\text { pneumoniae } \\
\text { ATTC700603 }\end{array}$ & $\begin{array}{r}5.8 \\
(0.1)\end{array}$ & $\begin{array}{r}6.1 \\
(0.3)\end{array}$ & $\begin{array}{r}7.2 \\
(0.2)\end{array}$ & $\begin{array}{r}8.2 \\
(0.2)\end{array}$ & $\begin{array}{l}14.0 \\
(0.2)\end{array}$ & $\begin{array}{l}15.4 \\
(0.4)\end{array}$ & $\begin{array}{r}5.8 \\
(0.2)\end{array}$ & $\begin{array}{r}5.9 \\
(0.1)\end{array}$ & $\begin{array}{r}6.2 \\
(0.2)\end{array}$ & $\begin{array}{r}8.1 \\
(1.7)\end{array}$ & $\begin{array}{l}10.1 \\
(0.1)\end{array}$ & $\begin{array}{l}15.0 \\
(0.1)\end{array}$ \\
\hline $\begin{array}{l}\text { Pseudomonas } \\
\text { aeruginosa } \\
\text { ATTC } 27853\end{array}$ & $\begin{array}{r}5.8 \\
(0.2)\end{array}$ & $\begin{array}{r}6.3 \\
(0.3)\end{array}$ & $\begin{array}{r}6.9 \\
(0.1)\end{array}$ & $\begin{array}{r}7.2 \\
(0.2)\end{array}$ & $\begin{array}{l}13.0 \\
(0.1)\end{array}$ & $\begin{array}{l}15.2 \\
(0.2)\end{array}$ & $\begin{array}{r}5.8 \\
(0.2)\end{array}$ & $\begin{array}{r}6.0 \\
(0.1)\end{array}$ & $\begin{array}{r}6.0 \\
(0.1)\end{array}$ & $\begin{array}{r}6.1 \\
(0.2)\end{array}$ & $\begin{array}{l}10.1 \\
(0.2)\end{array}$ & $\begin{array}{l}14.0 \\
(0.1)\end{array}$ \\
\hline
\end{tabular}

presented in Table III. The aerial parts of the extracts generally showed increase activity with increasing of the concentration against Gram positive bacteria and Gram negative bacteria. Both of the crude extracts exhibited the highest activity against Klebsiella pneumoniae $(15 \mathrm{~mm}$ at $100 \mathrm{mg} / \mathrm{mL})$.

\section{Anti-proliferative activity}

The anti-proliferaitve effects of the isolated compounds (rutin and tamarixetin), fraction T45-47 and n-butanol extract (rutin isolated from this fraction and extract) were evaluated against HeLa cell line. Real-time cell monitoring of the proliferation of the cells treated with the compounds for 48 hours period (Figure 3). n-Butanol extract and fraction T45-47 showed dose- and time- dependent effect. Tamarixetin exhibited significant antiproliferative effect against HeLa cell line ( $\mathrm{IC}_{50}<50 \mu \mathrm{g} /$ $\mathrm{mL})$, whereas rutin exhibited low cytotoxic effect $\left(\mathrm{IC}_{50}\right.$ $>100 \mu \mathrm{g} / \mathrm{mL}$ ). Figure 4 shows the anti-proliferative effect of the compounds on HeLa cells for 24 and 48 hours after the treatment at the concentrations of 10, 50 and $100 \mu \mathrm{g} / \mathrm{mL}$. Tamarixetin exhibited approximately $80 \%$ inhibitory effect at the highest concentration of 100 $\mu \mathrm{g} / \mathrm{mL}$.

\section{Discussion}

In this study, three known compounds were isolated from B. hispanica for the first time and their structures

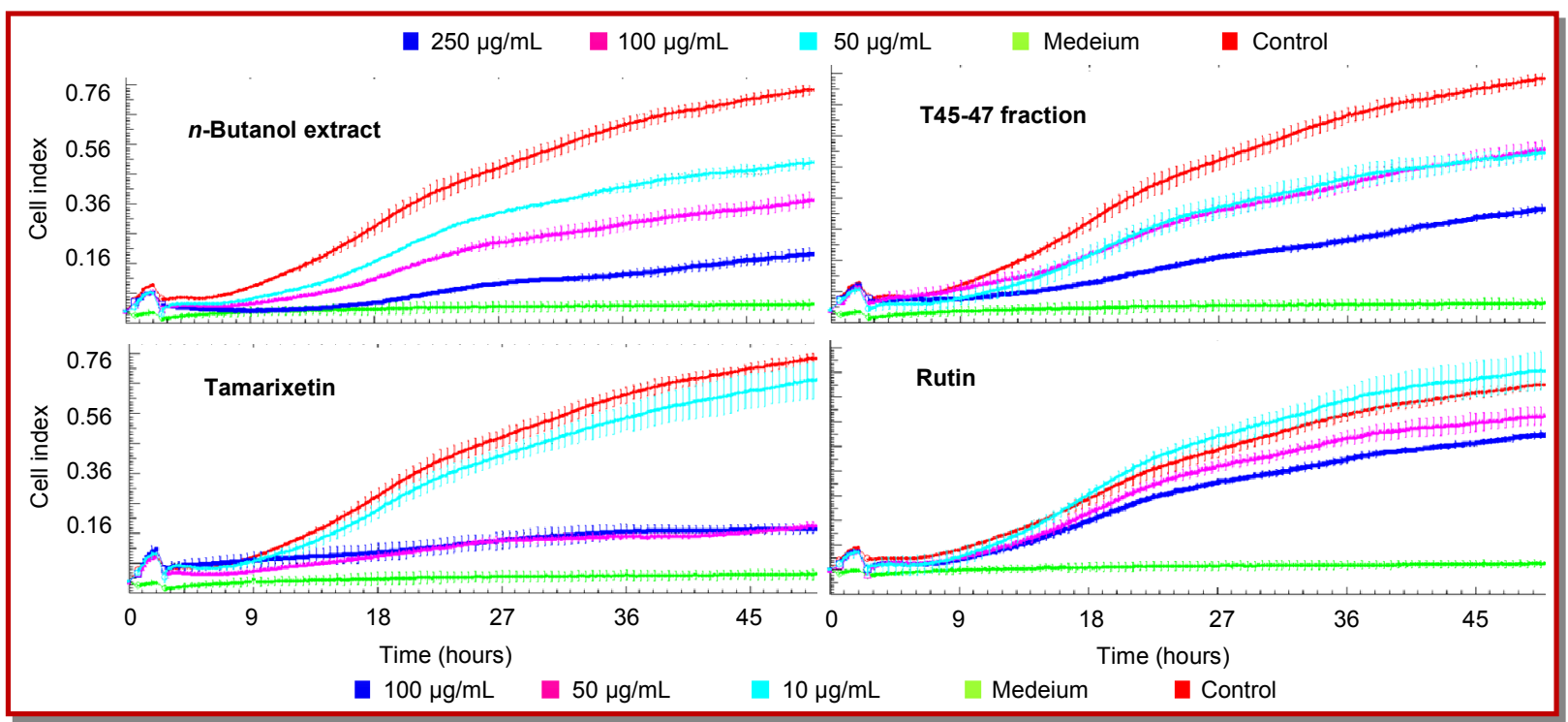

Figure 3: Anti-proliferative effect of the n-butanol extract, fractions T45-47, tamarixetin and rutin 

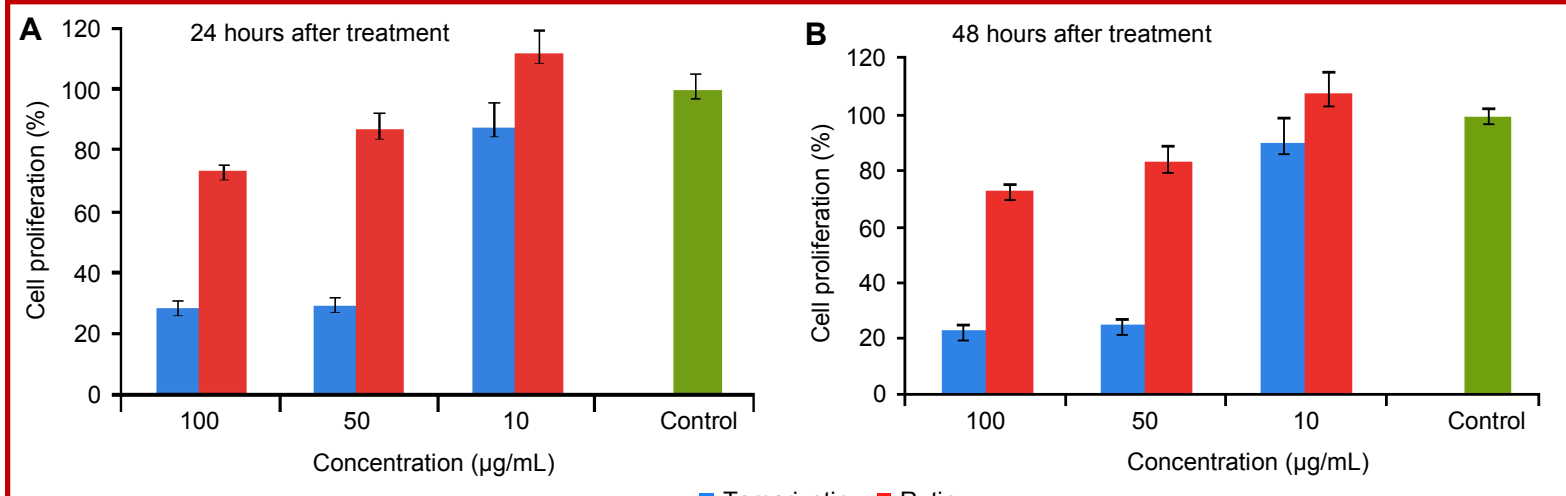

Tamarixetin Rutin

Figure 4: Cell proliferation (\%) for 24 and 48 hours after the sample treatment at tested concentrations

were elucidated as tamarixetin (1), caffeic acid (2) and rutin (3). In addition, anti-oxidant, antimicrobial and anti-proliferative activities of the samples from $B$. hispanica were evaluated. The extracts and fractions showed remerkable radical scavenging activity, especially fraction T36 exhibited higher radical scavenging effect than synthetic anti-oxidant BHT. To the best of our knowledge, there is only one study on B. hispanica about its anti-oxidant activity in the literature. Similar to our study, in the study of El-Youbi et al. (2012b), the aqueous extract of $B$. hispanica exhibited higher radical scavenging effect than BHT.

Berberis species is known to contain a variety of phenolic compounds which exhibit antibacterial potency (Birdsall and Kelly, 1997; Meenakshi et al., 2007). Both of the extracts have shown occurrence of phenolic and flavonoids content and that antibacterial actions may be due to their compounds content or could be belongs to the isolated compounds (tamarixetin and caffeic acide) from ethyl acetate extract of $B$. hispanica, which had been reported to inhibit the growth of different and same bacterial strains in this study (Sultanova et al., 2001; Alves et al., 2013), along with the presence of rutin compound in the $n$-butanol extract could be concluded that the antibacterial activity of this extract belongs to rutin (Basile et al., 2000). The result supports previously reported studies on antimicrobial activity of ethanol and water extracts from the root bark of B. hispanica against $M$. smegmatis, $M$. aurum and $S$. aureus activity (Amina et al., 2014; Ibtissem et al., 2017). The antibacterial results and occurrence of flavonoids and phenolic acid in crude extracts of B. hispanica are interest to discover new active plant compounds, and lead us to isolate more compounds for evaluate the antimicrobial activity of these extracts.

In this study, tested compounds inhibited the proliferation of HeLa cells in a dose- and time-dependent manner. Polyphenolic compounds from natural sources are currently of interest due to their possible anti-cancer activities (Greenwell et al., 2014). However, antiproliferative effects of tamarixetin on human tumor cells have a few assessed. In the present study, we examined the effects of tamarixetin on the growth of human cervical cell line and found that it displays significant anti-proliferative effect. Similar to our study, Nicolini et al. (2013) investigated the effects of tamarixetin on viability of some human tumor cell lines and found that it was cytotoxic against leukemia cells and in particular P-glycoprotein-overexpressing K562/ ADR cells. They indicated that tamarixetin inhibited proliferation in a concentration- and time-dependent manner, induced apoptosis and blocked cell cycle progression at G2-M phase. Delgado et al. (2014) reported that quercetin and its methylated metabolites including tamarixetin had significant anti-proliferative activity against breast (MCF-7), colon (Caco-2) and pancreas (BxPC-3) cancer cell lines.

On the other hand, in this study, rutin isolated from $B$. hispanica exhibited time and dose-dependent activity on HeLa cells. Some studies have been reported that rutin exhibited a dose- and time-dependent effect on U-937 and HT-60 (Srinivasan et al., 2016) and glistoma (Santos et al., 2011) cell lines. Rutin has also shown cytotoxic effects on several human cancer cells (Alonso-castro et al., 2011; ben-Sghaer et al., 2016). However, Kuntz et al. (1999) found that the flavonoids with glycosylated hydroxyl group (rutin, naringin) were not effective on human colon cancer cell lines. The remarkable antiproliferative activity by $B$. hispanica extract and fraction against human cervical cell line in our study might be due to the presence of anti-cancerous compounds, need to be isolated and identified for more investigation.

\section{Conclusion}

Tamarixetin, rutin and caffeic acid were isolated from B. hispanica. Tamarixetin exhibited a powerful cytotoxic effect on HeLa cells. Moreover, the crude extracts of $B$. hispanica exhibited remarkable antibacterial and antioxidant activities. This study supports the documented medicinal effects of $B$. hispanica and opens up the possibilities of pharmaceutical applications. 


\section{Conflict of Interest}

All authors have completed the ICMJE uniform disclosure form and declare no support from any organization for the submitted work.

\section{Acknowledgement}

This study was supported by the Ministere de l'Enseignement Superieur et de la Recherche Scientifique (MESRES-Alger, Algeria); Turkish State Planning Organization [grant number DPT2010K120720]; and Cankiri Karatekin University. The authors also acknowledge the help of Dr. Merve Banu Koc in performing the xCELLigence studies.

\section{References}

Alamzeb M, Khan MR, Ali S, Shah SQ, Rashid M. Antimicrobial properties of extracts and compounds isolated from Berberis jaeschkeana. Bangladesh J Pharmacol. 2013; 8: 107-09.

Alonso-Castro AJ, Domínguez F, García-Carrancá A. Rutin exerts antitumor effects on nude mice bearing SW480 tumor. Arch Med Res. 2013; 44: 346-51.

Alves MJ, Ferreira ICFR, Froufe HJC, Abreu RMV, Martins A, Pintado M. Antimicrobial activity of phenolic compounds identified in wild mushrooms, SAR analysis and docking studies. J Appl Microbiol. 2013; 115: 346-57.

Amina CH, Abdellatif H, Suzanna D, Saad I, Mohammed I. In vitro evaluation of the antimycobacterial activity and fractionation of Berberis hispanica root bark. J Pure Appl Microbiol. 2014; 8: 917-25.

Arora S, Kaur K, Kaur S. Indian medicinal plants as a reservoir of protective phytochemicals, Teratog Carcinog Mutagen. 2003; 23: 295-300.

Basile A, Sorbo S, Giordano S, Ricciardi L, Ferrara S, Montesano D, Cobianchi RC, Vuotto ML, Ferraro L. Antibacterial and allelopathic activity of extract from Castanea sativa leaves. Fitoterapia 2000; 71: 110-16.

Bellakhdar J. Moroccan traditional medicine, In: Ibis Press (eds), France, 1997, p 112.

Ben-Sghaier M, Pagano A, Mousslim M, Ammari Y, Kovacic H, Luis J. Rutin inhibits proliferation, attenuates superoxide production and decreases adhesion and migration of human cancerous cells. Biomed Pharmacother. 2016; 84: 1972-78.

Birdsall TC, Kelly GS. Berberine: Therapeutic potential of an alkaloid found in several medicinal plants. Altern Med Rev. 1997; 2: 94-103.

Blois MS. Anti-oxidant determinations by the use of a stable free radical. Nature 1958; 181: 1199-200.

Delgado L, Fernandes I, González-Manzano S, de Freitas V, Mateus N, Santos-Buelga C. Anti-proliferative effects of quercetin and catechin metabolites. Food Function. 2014; 5: 797-803.
El-Youbi AEH, Ouahidi I, Aarab L. In vitro immunomodulation effects of the aqueous and protein extracts of Berberis hispanica Boiss and Reut. (Family Berberidaceae). J Med Plant Res. 2012a; 6: 4239-46.

El-Youbi AEH, Bousta D, Jamoussi B, Greche H, El Mansouri L, Benjilali J, Soidrou SH. Activités anti-oxydante, apoptotique et anti-proliférative de Tetraena gaetula (Emb. \& Maire) Beier \& Thulin et de Berberis hispanica Boiss. \& Reut. originaires du Maroc. Phytothérapie 2012b; 10: 151-60.

Greenwell M, Rahman PKSM. Medicinal Plants: Their use in anti-cancer treatment. Int J Pharm Sci Res. 2015; 6: 4103-12.

Harish CA. Genus Berberis and Berberine HPLC: An overview. J Biol Active Prod Nat. 2012; 2: 256-64.

Hussain N, Adhikari A, Ahmad MS, Wahab A, Ali M, Choudhary MI. Two new prenylated flavonoids from the roots of Berberis thunbergii DC. Nat Prod Res. 2016; 31: 785-90.

Ibtissem A, Smain C, Youcef HP, Walter L. Isolation of berberinetannate using a chromatography activity-guided fractionation from root bark of Berberis hispanica Boiss. \& Reut. J Liq Chromatogr Relat Technol. 2017; 40: 894-99.

Kuntz S, Wenzel U, Daniel H. Comparative analysis of the effects of flavonoids on proliferation, cytotoxicity, and apoptosis in human colon cancer cell lines. Eur J Nutr. 1999; 38: $133-42$.

Meenakshi S, Sharad S, Rawat AKS. Antimicrobial activities of Indian Berberis species. Fitoterapia 2007; 78: 574-76.

Mokhber-Dezfuli N, Saeidnia S, Gohari AR, Kurepaz-Mahmoodabadi M. Phytochemistry and pharmacology of Berberis species. Pharmacogn Rev. 2014; 8: 8-15.

Nascimento GGF, Locatelli J, Freitas PC, Silva GL. Antibacterial activity of plant extracts and phytochemical on antibiotic resistant bacteria. Brazilian J Microbiol. 2000; 31: 247-56.

Nicolini F, Burmistrova O, Marrero MT, Torres F, Hernández C, Quintana J, Estevez F. Induction of G2/M phase arrest and apoptosis by the flavonoid tamarixetin on human leukemia cells. Mol Carcinog. 2014; 53: 939-50.

Oke-Altuntas F, Demirtas I, Tufekci AR, Koldas S, Gul F, Behcet L, Gecibesler HI. Inhibitory effects of the active components isolated from Satureja boissieri Hausskn. Ex Boiss. On human cervical cancer cell line. J Food Biochem. 2016; 40: 499-506.

Prakash V, Mishra PK, Mishra M. Screening of medicinal plant extracts for anti-oxidant activity. J Med Plant Res. 2009; 3: 608-12.

Santos BL, Silva AR, Pitanga BPS, Sousa CS, Grangeiro MS, Fragomeni BO, Coelho PLC, Oliveira MN, Menezes-Filho NJ, Costa MFD, El-Bachá RDS, Velozo ES, Sampaio GP, Freire SM, Tardy M, Costa SL. Antiproliferative, proapoptotic and morphogenic effects of the flavonoid rutin on human glioblastoma cells. Food Chem. 2011; 127: 404-11.

Servili M, Montedoro G. Contribution of phenolic compounds in virgin olive oil quality. Eur J Lipid Sci Technol. 2002; 104: 602-13.

Silva NCC, Fernandes Júnior A. Biological properties of 
medicinal plants: A review of their antimicrobial activity. J Venom Anim Toxins Tropical Dis. 2003; 16: 402-13.

Silva S, Gomes L, Leitão F, Coelho AV, Boas LV. Phenolic compounds and anti-oxidant activity of Olea europaea L. fruits and leaves. Food Sci Tech Int. 2006; 12: 385-96.

Singleton VL, Rossi JA. Colorimetry of total phenolics with phosphormolybdic-phosphotungstic acid reagent. Am J Enol Vitic. 1965; 16: 144-58.

Srinivasan R, Natarajan D, Shivakumar MS. In vitro evaluation of anti-oxidant, antiproliferative potentials of bioactive extract-cum-rutin compound isolated from Memecylon edule leaves and its molecular docking study. J Biol Active Prod
Nat. 2016; 6: 43-58.

Sultanova N, Makhmoor T, Abilov ZA, Parween Z, Omurkamzinova VB, Rahman AU, Choudhary MI. Anti-oxidant and antimicrobial activities of Tamarix ramosissima. J Ethnopharmacol. 2001; 78: 201-05.

Toudert N, Djilani SE, Djilani A. Antimicrobial activity of flavonoids of Ampelodesma mauritanica. American-Eurasian J Sustainable Agric. 2009; 3: 227-28.

Yamaguchi F, Ariga T, Yoshimura Y, Nakazawa H. Antioxidative and anti-glycation activity of garcinol from Garcinia indica fruit rind. J Agric Food Chem. 2000; 48: 180-85. 